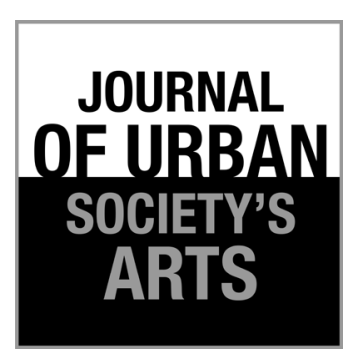

Volume 7 Nomor 1, April 2020: 21-29

\title{
EcoArt Through Various Approaches
}

\section{Dwi Marianto}

Program Studi Seni Murni, Fakultas Seni Rupa

Institut Seni Indonesia Yogyakarta.

Jln. Parangtritis KM. 6,5 Sewon, Yogyakarta.

Email: mdwimarianto@gmail.com; HP.: +62818462187

\begin{abstract}
This research was done as an effort to observe, write, and publicize eco-activism and achievements by a number of eco-actors in the midst of an increasingly natural environmental crisis, to be used as stimuli and teaching materials for the course of EcoArt. A number of artists practicing ecoartivism were purposively selected as a sample; their works and achievements are exposed. They are Endar Progresto, Widya Purwoko, Bernadeta Pudiasminarsih (Dyas Ecoprint), and Nasirun. These eco-activists not only work ecologically real, but also creatively communicate ecological values to surrounding communities to change. Nevertheless campaigning this environmental crisis for the better cannot be done partially, but must be jointly supported, organized and socialised continuously. For this reason, their works and achievements, as well as their individual ecoartivism need to be exposed, documented, and assembled as one unit as part of selected subjects of the EcoArt Course in the Fine Arts Department of the Indonesia Institute of the Arts Yogyakarta, to generate enthusiasm in articulating or representing ecological concerns for ecosystem sustainability and preservation of natural environment through Art.
\end{abstract}

Keywords: Endar Progresto; Dyas Ecoprint; Widya Poerwoko; Nasirun; EcoArt; Ecoartivism

\begin{abstract}
ABSTRAK
EcoArt Melalui Berbagai Pendekatan. Penelitian ini dilakukan sebagai upaya untuk mengamati, menulis, dan mempublikasikan ekoartivisme dan prestasi dari sejumlah ekoartivis di tengah-tengah krisis lingkungan hidup, untuk dipergunakan sebagai stimuli dan bahan ajar Mata Kuliah EcoArt. Sejumlah seniman yang mempraktikkan ekoartivisme dipilih sebagai studi kasus. Karya dan prestasi mereka diekspose dan diwacanakan. Mereka adalah Endar Progresto, Widya Purwoko, Bernadeta Pudiasminarsih, dan Nasirun. Keempat ekoartivist ini tidak hanya bekerja nyata secara ekologis, tetapi juga secara kreatif mengomunikasikan nilai-nilai ekologis kepada masyarakat sekitar untuk berubah. Krisis lingkungan ini tidak dapat ditangani secara partial, tetapi harus didukung dan dilakukan bersama-sama, diorganisir, dan disosialisasikan secara berkelanjutan. Untuk alasan ini, karya dan pencapaian mereka, serta ekoartivisme individual mereka perlu diekspos, didokumentasikan, dan dirangkai jadi satu kesatuan sebagai bagian dari mata kuliah EcoArt di Jurusan Seni Murni, Fakultas Seni Rupa, Institut Seni Indonesia Yogyakarta, untuk menghasilkan anthusiasme dalam mengartikulasikan atau merepresentasi seruan-seruan ekologis bagi kesinambungan ekosistem alam dan pelestarian lingkungan hidup melalui seni.

Kata kunci: Endar Progresto; Dyas Ecoprint; Widya Poerwoko; Nasirun; EcoArt; Ecoartivism
\end{abstract}




\section{Introduction}

"We are like islands in the middle of the ocean, on the surface the islands seem separated from one another, but in fact we are interconnected in the depths. Here, there are several layers of life through which we not only communicate with each other, in fact we are also part of each of us", William James. (In Ervin Laszlo, 2008)

The environmental crisis caused by human activity continues to occur everywhere, including the environment around the place and the institution where the author lives and works. (Photo 1). Various vernacular posters and banners, graffiti, actions and ecoartist works stated that many people from various backgrounds responded to the natural and life crisis in question. Some reactively express anger, and others represent it creatively, through creative work, inspiring socio-ecological actions. The second is what will be exposed and summarized as learning materials and illustrations that can motivate the course participants.

After noting the many inputs on various environmental crises that occur globally and locally, and heeding ecological calls that resonate globally, in 2014 the Department of Fine Arts, FSR ISI Yogyakarta began the EcoArt Course, as a compulsory subject. MK EcoArt is designed so that students have knowledge about the importance of the sustainability of natural ecosystems, so that they have an ecological awareness to participate in environmental preservation efforts, as part of their aesthetic concepts or creative work orientation. With and through the subjects discussed, or exposed and discussed, a number of things have been instilled, namely: a social-ecological understanding that everything is hooked up; also awareness that art/ design/craft is part of the dynamics of society and the environment. This kind of understanding and awareness is expected to be one of the important components to be represented through the work of the participants of the EcoArt course.

But in practice it is not easy to invite art learners to make ecological awareness as part of aesthetic or creative concepts. Habit if art is based on understanding "Art for Art", and commercialization of art is still too strong. The awareness that art is independent of its people is still deeply rooted. Support from other lecturers has not yet been felt, because they are still busy with the individualistic paradigm. The orientation of art learners is still so conventional, for example they tend to produce work as creatively or as coolly as possible, to be included in exhibitions or competitions, to become famous, and hope that their works are collected by many collectors and art galleries. The art of relational and cooperativebased has not been developed well in the academic environment.

The story above is still the same as the call to plant trees and care for the environment by making certain areas remain as green space (green open space) is still considered lightly, even completely ignored. Trees are still seen as mere objects/inanimate objects. Though the tree is a living creature, part of the universe, or as a cosmic antenna, every star that dies in the galaxy is recorded on the tree's circumference graphic. That is, plants (trees) and planets are connected and influence each other. (Fred Hageneder, 2001: 47).

A concrete example of this ignorance is what happened in August 2017 in downtown Bantul Regency, in an area not far from the ISI Campus in Yogyakarta, around 500 trees in their 20s were planted; with the reason for the implementation of the project work making road dividers. It is not a coincidence that when there was a massive flood that inundated areas in Bantul Regency in November 2017, along with a new storm called Hurricane Cempaka, which caused damage in a number of places, including the collapse of a bridge in the Kasihan area, Bantul. It is not a coincidence that a flash flood that occurred in November 2017 in Bantul Regency, which for the first time flooded the ISI Yogyakarta campus. The flood flooded the campus grounds and into classrooms. However, the same local government is not a deterrent, cutting down more than one hundred trees in September 2019, with the reason to revitalize the area.

The pattern of neglect of the same importance of green space occurs at the national level. The concrete illustration is the Monas Revitalization Project (National Monument) in Jakarta. In the third week of January 2020 the Jakarta people and 
netizens were shocked by the news about the felling of 190 large trees that were decades old on the south side of the National Monument. Ironically, the clearing occurred around the National Monument area in front of the DKI Jakarta Provincial Government Office; additionally the clearing of the trees took place when the community was large, and the DKI Jakarta Regional Government itself was busy busy fixing places and facilities that were badly damaged by flash floods which for several days inundated Jakarta and the surrounding areas, which occurred right on the first day of the year 2020.

The two illustrative samples above indicate that the management of green open space in the two regions mentioned above has not been ecological at all. So it is not surprising that there are more reports about environmental destruction that have caused significant material losses and fatalities in various media, including: 1) deforestation; 2) pollution of the sea and rivers due to various kinds of waste; 3) reduced green open space in urban areas; 4) the phenomenon of previously empty spaces in cities and villages used as landfills; 5) reduced habitat for various animals; 6) various illegal mining; 7) damage to the catchment area buffering various water sources, and many more that I do not mention here - given the limitations of space - the authors write in a special chapter discussing ecoart in the book Art \& Living Power in Quantum Perspectives. (Marianto, 2019: 259-287)

As is well known, a variety of environmental and ecosystem damage has a direct impact on the lives of the community together, causing a decrease in the carrying capacity of the environment, and resulting in a decline in the quality of life of the community. As an illustration, due to the lack of public facilities such as green open space that is easily accessible to the local community, in the afternoon many parents and their children come to a place around the crossing of the road and railroad tracks near Patukan Station, Ambarketawang, Yogyakarta, sitting on the railroad tracks while looking at the passing trains as entertainment for small children. (See Photo 1)

Therefore, a measurable and continuous range of collaborative efforts - mutual cooperation or ngayah (in Bali) to campaign for joint actions for the sustainability of the ecosystem, and disseminate innovative works in design, art, crafts and architecture to the community to arouse the wider community. in Indonesia preserving the environment and the sustainability of natural ecosystems and the environment as a living capital and a manifestation of values that we strive for together as a pluralistic nation, consisting of various ethnicities, ethnicities, and religions.

As a guide to the EcoArt Course, the author requires a variety of knowledge about EcoArt, which can be obtained from various sources, including from various sources of knowledge about EcoArt, praxis ecoartivism (ecoartivism), models or concrete examples of concrete EcoArt practices and convincingly it has been concreted by ecoactivists, to be compiled, reduced and assembled creatively. This creative assembly is then used as teaching material and discussion material, as well as models that are expected to inspire and inspire MK EcoArt participants.

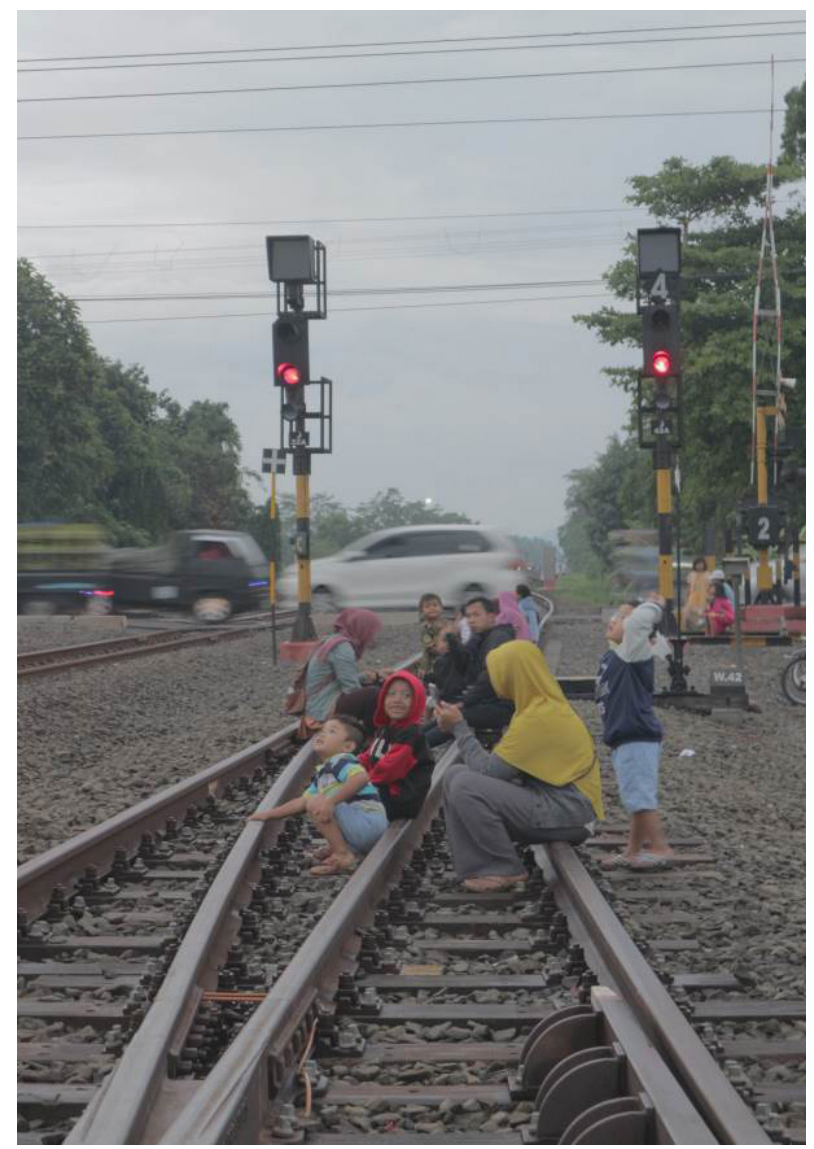

Figure 1 . The daily view every dusk around the railroad crossing in Patukan, Ambarketang, Gamping, Yogyakarta. Source: VQ Satrio 
Eco-art is ecological art with a purpose, which is created by artists who are concerned with the state of both local and global environmental situations. The word "eco" is Greek in origin, and means "home", and of course, the word "art" is selfexplanatory. Eco-art concerns itself with ecological activism and the highlighting of issues. (Eco-art. org)

\section{Methods}

EcoArt can be regarded as a concept of preserving ecosystems and the natural environment based on artistic creativity / design. At this stage we are looking for forms and rhythms of EcoArt learning, still through practical and pragmatic views only, namely observing, collecting data and information, documenting, discussing ecoartivist products from selected subjects to be arranged purposively for teaching needs. In understanding the diverse actions, works, views and aesthetic concepts of the research subjects on EcoArt, the writer uses the understanding that everything is connected, interconnected, and influences each other. We illuminate the fruits of their creativity and innovation with the understanding that they have moved and worked through a multi-modality approach - in the sense of creative thinking by assembling creative potential in multi-media, intermedia, and cross media (Adya Arsita et.al , 2019), conventional and unconventional techniques can be used, insofar as they can inspire others to be ecologically conscious and innovate.

In this presentation, several EcoArt practitioners and activities will be exposed, namely: Endar Progresto, Dyas Ecoprint, Tisna Sanjaya, Widya Poerwoko, and Nasirun. They are a sample of some of the figures we discussed in the EcoArt Class.

\section{EcoArt Practitioners}

EcoArt is the practice of using art as a tool for the advocacy of the preservation, restoration, or improvement of the natural environment; especially: the movement to control pollution. While all artists are meaning-makers of the world in which we live, those that I refer to as "ecoartivists" use their artistic expression to connect the rest of us to the environment, which we all too often take for granted. In addition to the need for selfexpression, these artists find they have a calling to protect and care for the physical world we inhabit. (Stacey Ward Kelly)

In her article "Cultivating artistic approaches to environmental learning: Exploring eco-art education in elementary classrooms" Hilary J. Inwood mentions one her research member Karen- who states that eco-art is all art that conveys a respect for the earth, for our natural environment, the interconnectedness of our eco systems, and the importance of ecological literacy... I think the bottom line for me was always respect.

The following are the four selected ecoartivists that the author visited, interviewed at work, and at their studios, as well as public spaces where they socialized their work and ecoartivism.

\section{Endar Progresto}

Is an applied design practitioner (born 1968) who lives and works in Klego, Boyolali, his hometown. He did a lot of building building signs for offices, shops, houses of worship; also accepts orders to make posters, banners; and photography and video production services. The Graphic Arts Department alumnus, FSR ISI Yogyakarta has successfully developed screen printing techniques for various businesses. Activities outside of his business work are planting barren hills due to illegal logging around the area where he lives.

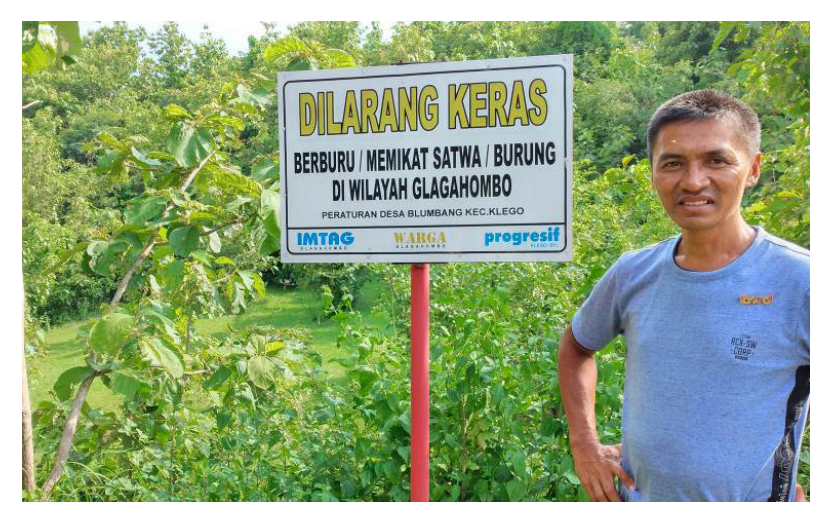

Figure 2. Endar Progresto when asked to pose for a photo next to a environmental conservation campaign poster which he made. Along with the local youth of his community, he distributed those posters in many places around Klego, Boyolali. January 2020. Photo by M Dwi Marianto 
The work of planting trees in hilly areas is imagined like the work of painting, but not with paints from factory-made tubes, but with the natural colors of trees planted and living in the area in question. (See "Endar Progresto" on Youtube). He has planted trees individually and collectively, as well as what he has done en masse since 2000 . One of the areas that has been successfully restored is the Wonopotro hill area, in Klego District, Boyolali.

It turns out that water likes the living trees' roots. In several places that are now green there have emerged springs, whose water flow is now managed by the Regional Water Supply Company. The area is now a nature reserve area which in recent years has been managed through a CSR program from one of the leading national oil company - Pertamina. In addition, since 2008 Endar has long initiated environmental conservation campaigns, which are carried out and self-funded, in collaboration with young people in the surrounding areas, including making various signboards that campaign for environmental, animal and fauna, and ecosystem conservation. (See figure 2)

\section{Dyaz Ecoprint}

Is a popular name of an Ecoprint practitioner, its work and activities can be included in the scope of EcoArt. He experimented and developed tasting and coloring techniques, using leaves from several types of trees. His real name is Bernadeta Pudiasminarsih (born in Klaten, 1974). Since 2016 Dyaz has developed his creative concept with three

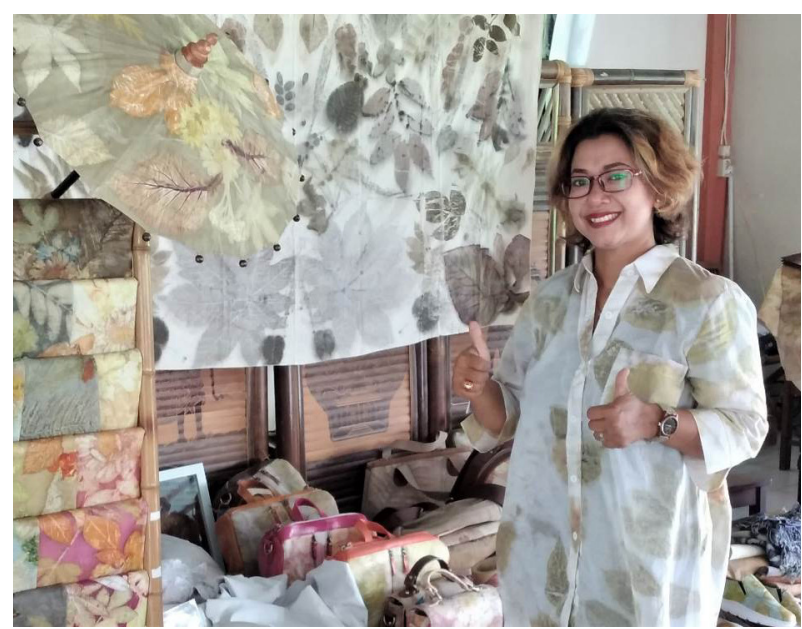

Figure 3. Dyas Ecoprint, a totally dedicated Ecoprint practitioner, who pays great attentions to seeds, and plants various trees in her backyard. Photo by M Dwi Marianto points that become his creative concept elements, namely: using leaves as print media, but only picking leaves as needed, paying attention to the seeds of various types of trees, and planting trees in every empty space in his home, and in his garden his extended family in Klaten, Central Java, for the sake of the sustainability of his ecoprint activities, and more importantly for the sustainability of the environmental ecosystem. His daily activity is providing training in seminars, workshops, and counseling for many parties from many institutions. This means that he has disseminated the achievements of his innovation, his attitude to the preservation of ecosystems, and his concern for the community and the environment. (See Figure 3)

\section{Widya Poerwoko}

Is a martial art instructor who has a background in interior designer education, who then takes doctoral studies at ISI Yogyakarta because of his concern over sand mining in the area around the foot of Mount Merapi, which is increasingly still and intense. Ecosystem sustainability is threatened, the preservation of the natural environment is gradually disrupted, because fertile soils are dug with large-powered machines, to take a layer of sand on the surface. A fertile layer of land, of course, explained me. Leaving arid soils, tuna plants. Even though he himself lives in the area of the foot of Merapi, which is in an area called Cangkringan which is not too far from the places where the sand was taken. (See Widya Purwoko, 2019)

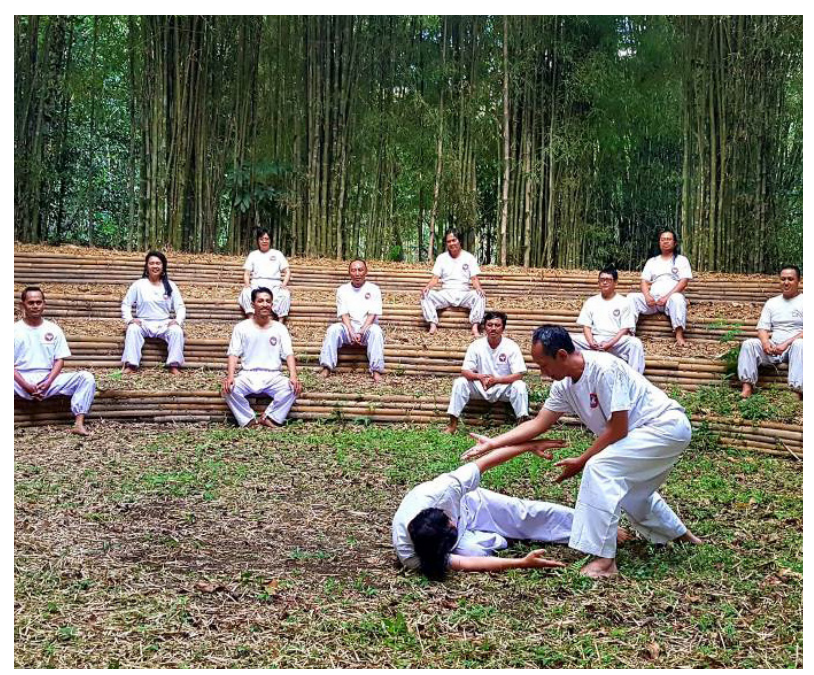

Figure 4. Integrated Space Design Installation, for various eco-artism-based activities. Photo by Widya Poerwoko 
The former sand mining land which is now inhabited, has been revived by planting various types of trees, but mainly bamboo plants - which are giant vegetation. The bamboo is made a living medium, with what he makes several bamboo installations that are different from one another.

He has already made seven installations whose concepts he picked from 9 philosophical points from the White Crane PGB. His work entitled "Bamboo and Spirituality in Integrated Space Design", as a forum for organizing various activities, ranging from martial arts training, meetings for academic activities, culinary bazzar, and as a space for a cultural gathering of the surrounding communities and other communities that care about the preservation of culture and the environment. (See figure 4)

\section{Nasirun}

Is a famous artist, born in Cilacap in 1964. He lives in Yogyakarta, which has a network of various backgrounds, from within and outside the country. He once gave a plot of land behind his house which had been used for years as a place to dispose glass waste. A patch of land that is barren, scary, and bad. From the sale of his paintings and batik, he gave the land, was cleared by a number of artisans for the responsibility of the Nasirun. The collected waste glass is used as part of the building foundation built near the site; trees are planted around land that has been free of glass waste.

After a number of trees around the land live and grow, the roots become water invitations to

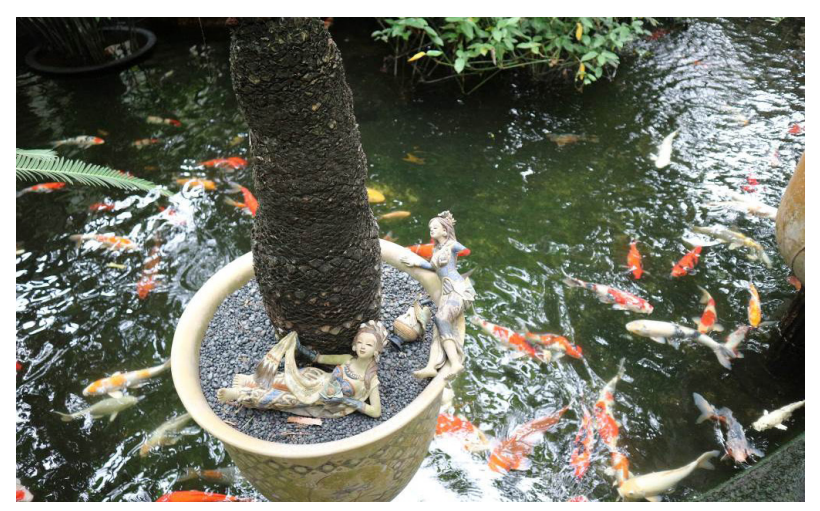

Figure 5. Fish pond at Nasirun's backyard at Perum Bayeman Permai in Jalan Wates KM 3, Yogyakarta. The place was formerly a landfill for glass industry waste that was vile and disgusting. The water for this fish pond is from a well-managed natural spring. Photo by M Dwi Marianto flow to the relevant plants. Behind his relatively large house, there are two springs which he manages for swimming, and a swimming pool. The yard of the house and studio were filled with a variety of rare trees, which apparently inspired neighbouring communities to join in planting their respective homes with trees of their taste. In fact now, the environment where Nasirun and his family live is very cool, various kinds of birds are free to roam. In some of his land bought from the sale of paintings, he let it become green space, which is inhabited by a variety of rare trees. He distributed his ecological work and attitude to the environment through various communities and individuals who came to the studios and museums where he kept and displayed collection works. Besides all that, there was one Nasirun answer that surprised the writer when he asked him around 2015 about the reason why he was so enthusiastic about planting rare trees. The answer to that question so surprised the author, like this: ".... because the tree is actually a cosmic antenna”. (See Figure 5)

\section{The EcoArt Course}

The EcoArt course offered by the Fine Arts Department is still in the road to discovering its right format, method, and substance, in order to represent the ecological values through ecoactivism. We are still searching any paradigm and ways appropriate to the context of ecological problems nowadays and the education character of ISI Yogyakarta. Some perspectives about alternating relations between art and the ecosystem have already been achieved, including the following:

Susi Gablik's perspective on the relation between art and her surroundings is a perspective which states that art has to have an alternating relation to its surroundings, as conveyed in one of her book The Reenchantment of Art, Gablik, Suzi (1983), London: Thames and Hudson.

The truth now being acknowledged is the fact, art included, that all are interconnected, intertwined, and interplay. Art can never be pure and does not stand alone, or separated from its environment. Such art will die. Therefore, we will never view art simply as 
an aesthetic expression, but must also link it to the its present surrounding. The real and most relevant way to view art is by the relations to the environment, so that the separation of art from the community can be minimized.

\section{Laudato Si}

This is the Highest Ranking Vatican Document (Encyclical) of Pope Francis which was issued in 2015. "Laudato Si" which is translated as "Praise Be to You" contains the reflection and the moral invitation from the highest leader of one of the greatest religion in the world to see and comprehend the disruption and destruction of Nature and the environment, and a way to cope with it. Francis called for Ecological Repentance for humanity to turn to ecological awareness to respect the environment — created by God Almighty — and to care for it as part of faith. In other words, people with faith of God The All Forgiving must regard nature as the creation of the Almighty Creator. Francis states that the caring for the Earth, the environment, and loving all living beings is not an option, but an obligation. Because humans are part of the environment and each other.

Francis also conveyed that the destruction, the exploitation of nature and the disruption of the environment, is not simply done by physical actions, but also by sheer instinctive motives that are driven by perspective that are philosophically, theologically, and/or culturally wrongful. For example, the urge to gain social-economic benefit, or to gain political power, many parties are massively exploiting nature and the environment without regarding for the sustainability of the ecosystem for the local community, and other living beings; the flora and fauna. Or, the help of armed politics and power concessions given by one of the opposing parties, in order to gain control of the area that are known for its mineral resources and valuable resources to be exploited freely.

The Encyclical, dated May 24, 2015, was generally publicized on June 2015 with translations to the following languages: Italian, German, English, Spanish, French, Portuguese, Arab, and Latin. This document contains a number of principal points to sort out various problems on global ecological issues; noble teachings about The Creator and his creations; the roots to human problems that results on ecological crises; integral ecology; approach methods and ecological actions; as well as spiritual and ecological educations. Through this document Pope Francis calls for humanity and all nations to rally in peace in order to overcome the Global Environmental Crises.

\section{Relations Between Plants and Planets}

From the book The Spirit of Tree the author developed an understanding that is relevant to EcoArt, namely: "Without trees there are no leaves, without leaves there is no ecoprint". It is true the proverb of Northern Europeans who say that trees are the guardians of life and death. Because the old Germans used to bury their dead with wood from special trees. Just like the burial tradition for young children who died in Toraja culture; jazad to be buried put in the hole of one type of tree called Taraa - a type of plant that emits a lot of white sap, which is seen as mother's milk for breastfeeding her child. The leaves, which are generally green, provide colorful material for ecoprints. It is truly miraculous, so there must continue to be conservation efforts that are effective, innovative, together with the spirit of continuous mutual cooperation. (Hagender, p. 67)

Representation of ecosystem and environmental preservation issues does not have to be spectacular on a large scale, but is continually carried out, communicated and conveyed continuously in an intelligent, attractive manner. Making ecoprints, for example, does not require large costs, or sophisticated equipment and a large workplace, enough with a healthy and open space for steaming cloths that have been attached to leaves, and later for fixation. The most important thing is to socialize the attention of tree seeds, to be planted, cared for and harvested sufficiently.

\section{Multi-Modalitay Approaches}

EcoArt representation can be done through various approaches, from conventional to 
unconventional methods; from simple media to the use of ambient media; through performance art, installations, happening art, or working on unique sites to exploit its unique and unique character and atmosphere. In short, anything that is good, aesthetic, and arouses ecological awareness and creativity should be explored, realized, and developed as what the above discussed ecoartists has done. In short any creative / innovative activities through any media that are able to open ecoaesthetic awareness of many people to participate in preserving ecosystems and the environment by, in, with, or through art can be put into the term "ecoartivism"..

This multimodality approach is in line with the approach stated by Inwood in relation to ecoart education that integrates knowledge, skills, values and pedagogy from the visual arts, art education and environmental education as a means of developing awareness of and engagement with environmental concepts and issues such as place, interdependence, systems-thinking, biodiversity, and conservation.

\section{Conclusion}

Environmental problems that puts a threat to ecosystem sustainability and other living creatures - flora and fauna-is still happening in this country. The reduction on green open spaces and the pollution of rivers, lakes, the sea, and the ocean is constantly happening at an alarming rate. The comprehension, knowledge, and awareness of the importance to ecosystem preservation for the sake of communal livelihood should be continuously strived for by the several means and with the help of the media.

Those four eco-activists are research subjects who are the few samples of the eco-activists who struggle for their own methods and causes; some of them are already known publicly while the others are yet to be noticed. In this term, the role of exposure, in-depth observation, and publication or ecologically innovative achievements is very important and strategic. Data information, exposure, and publications in the form of texts, artworks, videos, and performances by subjects of this nation is very important for students to learn about EcoArt.

At least, the writer will feel helped and can deliver his teaching materials more informatively; and will also be more confident to motivate EcoArt scholars and to exhibit their inspiring works. Concern for the preservation of the environment and environmental ecosystems needs to be articulated through interesting media, convincing intelligently, innovatively through eco-artism so that more individuals and communities live ecologically.

Last but not least, EcoArt and Eco-artism must be tapped and sounded synergistically, through communication, collaboration, and good and continuous cooperation. Among them through Art Education/Design/Architecture. As a closing remark, let us examine the meaning of the series of words below:

\section{Prayers from Lithuania}

Let's us not cut down trees without holy needs; do not arrange it into a flower garden. Let me always plant trees. The gods/goddess happily look at people who plant trees along the road, at home, in holy places, at crossroads and in homes.

When you have a marriage, plant a tree to mark the marriage. When a child is born, plant a tree. When our loved ones die, plant a special tree for their souls.

At every festival, on every important occasion, visit the trees. Prayers are glorified by trees.

\section{References}

Goethe Institut. (2015). "SENI DAN LINGKUNGAN". Katalog Pameran. Bandung: Gedung Yayasan Pusat Kebudayaan, Goethe Institut, Bandung.

Arsita, Adya (2019), "Multimodal Approach in Advancing the Visual Literacy". Proceeding of ICONARTIES 2019. DOI. $10.5220 / 0008544200140019$.

Danesi, Marcel (2004), Messages, Signs, and Meaning: A Basic Textbook in Semiotics and Sommunication Theory. Toronto: Canadian 
Scholar's Press.

Francis, Pope Francis. Praise Be To You (Laudato

Si). San Francisco: Ignatius Press)

Gablik, Suzi (1983). The Reenchantment of Art. London: Thames and Hudson.

Hageneder, Fred (2001). The Spirit of Trees: Science, Symbiosis, and Inspiration. New York: Continuum.

Heyrman, Hugo, "Art and Synesthesia: in search of the synesthetic experience", Lecture presented in the First International Conference on Art and Synesthesia, 25-28 July 2005.

Inwood, Hilary J. (2013). Cultivating artistic approaches to environmental learning: Exploring eco-art education in elementary classrooms. International Electronic Journal of Environmental Education. .3(2), 129-145

Laszlo, Ervin. (2008). Quantum Shift in Global Brain. Rochester: Inner Tradition.

Marianto, M. Dwi (2019). Seni \& Daya Hidup dalam PerspektifQuantum. Yogyakarta: Scritto Books.

Poerwoko, Widya, (2019), "ECO-ART Bambu dan Spiritualitas Silat dalam Integrated Space Design”, Disertasi, PPs ISI Yogyakarta.

Ramachandran, V.S. (2012). The Tell-Tale Brain. Unlocking the Mystery of Human Nature, London: Windmill Books.

Sousanis, Nick (2015). Unflattening. London: Harvard University Press. 